\title{
When is it biological control? A framework of definitions, mechanisms, and classifications
}

\author{
Johan A. Stenberg ${ }^{1}\left(\mathbb{D} \cdot\right.$ Ingvar Sundh $^{2}\left(\mathbb{0} \cdot\right.$ Paul G. Becher $^{1}\left(\mathbb{D} \cdot\right.$ Christer Björkman $^{3} \cdot$ Mukesh Dubey $^{4}(\mathbb{D})$

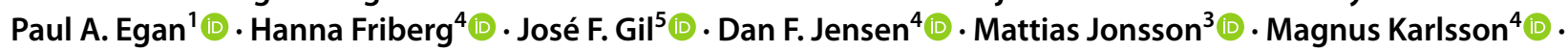

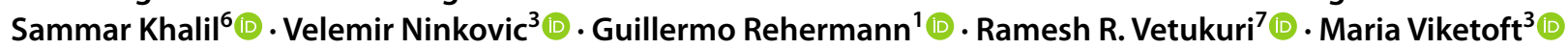

Received: 16 October 2020 / Revised: 15 February 2021 / Accepted: 17 February 2021 / Published online: 13 March 2021

(c) The Author(s) 2021

\begin{abstract}
Biological control, or biocontrol, is the exploitation of living agents (incl. viruses) to combat pestilential organisms (incl. pathogens, pests, and weeds) for diverse purposes to provide human benefits. Thus, during the last century the practices and concepts involved have evolved in separate streams associated with distinct scientific and taxonomic disciplines. In parallel developments, there have been increasing references to biological control in industrial contexts and legislation, resulting in conceptual and terminological disintegration. The aim of this paper is to provide a global conceptual and terminological platform that facilitates future development of the field. We review use of previously suggested terms in key fields (e.g., phytopathology, entomology, and weed science), eliminate redundant terminology, identify three principles that should underpin the concept, and then present a new framework for biological control, rooted in seminal publications. The three principles establish that (1) only living agents can mediate biological control, (2) biological control always targets a pest, directly or indirectly, and (3) all biocontrol methods can be classified in four main categories depending on whether resident agents are utilized, with or without targeted human intervention (conservation biological control and natural biological control, respectively) or agents are added for permanent or temporary establishment (classical biological control and augmentative biological control, respectively). Correct identification of what is, and is not, biological control can help efforts to understand and optimize biological pest control for human and environmental benefits. The new conceptual framework may contribute to more uniform and appropriate regulatory approaches to biological control, and more efficient authorization and application of biocontrol products.
\end{abstract}

Keywords Biocontrol $\cdot$ Biological control $\cdot$ Bioprotection $\cdot$ Ecosystem service $\cdot$ Integrated pest management $\cdot$ Soil suppressiveness

Communicated by Antonio Biondi.

Johan A. Stenberg

johan.stenberg@slu.se

1 Department of Plant Protection Biology, Swedish University of Agricultural Sciences, Alnarp, Sweden

2 Department of Molecular Sciences, Swedish University of Agricultural Sciences, Uppsala, Sweden

3 Department of Ecology, Swedish University of Agricultural Sciences, Uppsala, Sweden

4 Department of Forest Mycology and Plant Pathology, Swedish University of Agricultural Sciences, Uppsala, Sweden
5 Department of Plant Biology, Swedish University of Agricultural Sciences, Uppsala, Sweden

6 Department of Biosystems and Technology, Swedish University of Agricultural Sciences, Alnarp, Sweden

7 Department of Plant Breeding, Swedish University of Agricultural Sciences, Alnarp, Sweden 


\section{Key message}

- Living biocontrol agents and non-living nature-based substances provide separate forms of bioprotection.

- Biocontrol mechanisms target a pest, directly or indirectly, thus excluding, e.g., biostimulation.

- Conservation and natural biocontrol involve resident agents with and without intervention.

- Classical and augmentative biocontrol involve agents added for permanent and temporary control, respectively.

- Clear definition and understanding of biocontrol will facilitate efficient regulation and implementation.

\section{Introduction}

The term biological control (or biocontrol) has been used for more than a century (Smith 1919), and it has been applied in practice to almost all types of pests. Examples include insect pests and pathogens of crops (Pertot et al. 2017), weeds, mosquitos (Ingabire et al. 2017), and rodents (Jäkel et al. 2019; Labuschagne et al. 2016). In addition, the principles of biological control underlie actions of protective antagonists in the food chain, e.g., in food and animal feed processing (Jordan et al. 2014), as well as important medical treatments for humans (Dedrick et al. 2019; van Nood et al. 2013), although different sets of terminology are used in these disciplines. Notably, the demand for biocontrol solutions has rapidly grown in recent years in parallel with global endorsement of integrated pest management (IPM) as the future paradigm for crop protection (Stenberg 2017). In the text and conceptual framework presented here, we treat all pestilential living things, including pathogens and weeds, as pests. This is also consistent with etymological roots of the words pest (Latin, pestis: pestilence, plague, curse, destruction; online-latin-dictionary.com) and pathogen (portmanteau of the Greek words, pathos and gen: producer of suffering or disease; dictionary.com).

As biological control developed as a pest management strategy in the twentieth century, new agents involving various mechanisms were employed and the need for new classifications and a uniform terminology arose. Unfortunately, however, the rapid spread and development of biological control in practice, and corresponding growth in related research, led to fragmentation into sub-disciplines (Barratt et al. 2018). This contributed to terminological anarchy and weakened the conceptual framework. For example, in seminal books on biological control of plant pathogens, Baker and Cook $(1974,1983)$ noted that their definitions and terminology differed from those of entomologists (and there was even divergence within entomology). This divergence continued for several decades, prompting Eilenberg et al. (2001) and later Heimpel and Mills (2017) to suggest a unifying terminology that could be accepted in all areas of biological control. They had some success as their definitions and classifications have been adopted and followed by many entomologists, but they are still largely neglected by pathologists and weed scientists, as well as various industrialists, policy-makers, and other stakeholders. Thus, as demand for biological control as an element of IPM is soaring, there are increasingly urgent needs for cross-discipline terminological and conceptual harmonization.

Despite the separate and divisive development between pathologists and entomologists, the general term biological control has acquired positive connotations in society, prompting both industrial and scientific interest groups to stretch the concept to include use of related, biologically derived agents and products (Gray et al. 2018; Santos et al. 2011). Regardless of the intentions (which may range from convenience to opportunism), this has further blurred and diluted the concept, leading to continuing erosion of the term's meaning and relevance. Although Baker and Cook (1974, 1983), Eilenberg et al. (2001), and Heimpel and Mills (2017) among others have called for conceptual orthodoxy, for various reasons the terminology is still frequently misused.

The terminological misuse and confusion clearly hinders cross-disciplinary scientific coherence and productive communication between researchers, legislators, and the biocontrol industry, at both national and international levels in the authorization and implementation of biocontrol products. Such interactions are complicated by the frequent use of inconsistently defined terms like bioactive products, bioprotection, bioprotective, biopesticides, biofertilizers, and biostimulants. Thus, there are increasingly urgent needs to extend the efforts of Baker and Cook (1974, 1983), Eilenberg et al. (2001), and Heimpel and Mills (2017) to address the terminological issues.

The aim of this paper is to contribute to the deep pruning required in the conceptualization underlying biological control, thereby providing a global terminological and conceptual platform that can facilitate future development of the field. While it is important to conceptually define biological control, and key criteria of biological control agents or practices, it is equally important to clarify how biological control is related to other types of control and practices to facilitate the interdisciplinary synergies coveted within, for instance, IPM.

The conceptual framework developed in this paper is based on three principles: only living agents can mediate biological 
control, it always targets a pest, and all biocontrol methods can be classified in four main categories. Recognition and appropriate application of these three principles is not a trivial matter, as it will greatly help understanding, optimization, and regulation of biological pest control for human and environmental benefits.

\section{Agents of biological control}

\section{Living agents in three-way interactions}

The term biological control has traditionally been used to describe actions to combat pests using other living agents. Baker and Cook $(1974,1983)$ defined it as "the reduction in the amount of inoculum or disease-producing activity of a pathogen accomplished by or through one or more organisms other than man." Thus, their definition is restricted to control of pathogens. When Eilenberg et al. (2001) later attempted to harmonize a terminology that was already diverging in several directions, they emphasized that the term biological control should exclusively be used for living agents, excluding all other natural or semi-natural agents.

Cook \& Baker (1983) suggested that plants could be their own living biocontrol agents by being intrinsically resistant to pests and pathogens. This suggestion was not widely adopted within the scientific community (Heimpel and Mills 2017), and here we reject their proposal and maintain that no organism can be its own bodyguard. Instead, biological control should only be recognized in interactions between three separate players: (1) a pest, (2) a living biocontrol agent targeting the pest, and 3) a human stakeholder benefitting from the pest control service provided by the biocontrol agent (Box 1).

In the crop protection discipline, the term biological control has not been commonly applied to activities of companion plants that reduce, through various mechanisms, pest damage to focal crop plants. Living plants were probably excluded previously for historic reasons, because notions of associational resistance-which generally refers to reductions in herbivory of a plant mediated through growth with heterospecific neighbors (Tahvanainen and Root 1972)_-and connected concepts developed in other scientific traditions. From a conceptual point of view, however, there is no reason to deliberately exclude living plants from roles as agents of biological control.

\section{Viruses}

Viruses are biological entities, but they are not always defined as living organisms (Forterre 2010; Koonin and Starokadomskyy 2016). Nevertheless, previous seminal papers on biological control did not exclude them from groups of possible biological control agents. Baker and Cook $(1973,1984)$ did not discuss viruses as agents at all, but Eilenberg et al. (2001) and Heimpel \& Mills (2017) embraced them as valid agents. In recent decades, viruses have been increasingly widely used to combat pests both directly (by pathogenic pest infection) and indirectly (e.g., by cross-protection, i.e., 'vaccinating' crops with mild virus strains), and placed in the canon of biological control with no conceptual opposition from the scientific community (Di Giallonardo and Holmes 2015; Falcon 1982). Viruses undeniably lack several of the accepted distinguishing features of living organisms, but they include the key structural components of living organisms (nucleic acids and proteins), they mutate and evolve, and they reproduce via the exploitation of living organisms' systems in ways that no simple substance can. We regard them not as living organisms, but certainly as valid agents of biological control, and hence include them (with these caveats) within our definition of living agents.

\section{The bioprotection umbrella}

In parallel with growing environmental awareness among farmers and consumers, various new products with bio-prefixes have been introduced for crop protection. Some of these contain living organisms, while others contain nature-based, non-living, active ingredients. For conceptual and regulatory reasons, there is a need to maintain a clear distinction between these categories, but for commercial reasons there is a clear tendency to blur them. To avoid some associated terminological problems (or contribute to the blurring, depending on one's perspective), the International Biocontrol Manufacturers' Association (IBMA) promotes the broader term bioprotection (previously adopted by, e.g., the Bio-Protection Research Centre of New Zealand, https://bioprotection.org.nz, and BioProtection Global, https://www.bioprotectionglobal.org), which encompasses protection provided by all tools of biological origin for management of pests, pathogens, and weeds. According to the IBMA, bioprotection agents should "originate from nature or [be] nature-identical when synthesized and in general

Box 1 Definition of biological control

Biological control is the exploitation of living agents (including viruses) to combat pestilential organisms (pests and pathogens), directly or indirectly, for human good. Biological control must always involve the following three separate players:

1) a biocontrol agent,

2) a pest, and

3) a human stakeholder benefitting from the pest control service provided by the biocontrol agent. 
have a low impact on human health and the environment" (International Biocontrol Manufacturers Association 2018).

We believe that bioprotection can be used as an excellent umbrella term that encompasses protection provided by

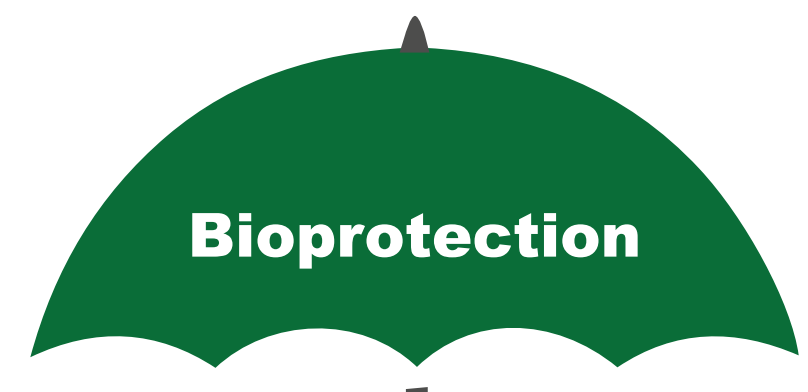

\section{Biological control agents \\ Nature-based substances}

(living)

Fig. 1 The bioprotection umbrella, covering living biocontrol agents and non-living, nature-based, substances. Either class can provide potent protection against pests, but it is important to maintain a clear conceptual boundary between them for scientific and regulatory reasons

either living agents or non-living substances of biological origin (Fig. 1). Inhabiting separate halves under the umbrella we may - without hierarchical discrimination - appreciate the ground-breaking and sustainable value of non-living "natural" substances included in, e.g., plant-derived substances (Isman 2006), semiochemicals (Bruce et al. 2005; Witzgall et al. 2010), protein applications (Thakur and Sohal 2013), and RNA interference (Koch et al. 2016; Zhu et al. 2011). The separating umbrella shaft avoids classifying nonliving "natural" substances as biocontrol agents, and thereby the terminological confusion such mis-identification would bring about. The non-living components may indeed be part of the biocontrol mechanism when produced by living organisms in situ (see next paragraph, below). However, to preserve scientific clarity and integrity of biological control we suggest keeping the boundary between the living agents within biological control and the non-living substances in other forms of bioprotection.

\section{Mechanisms of biological control}

Identifying the mechanisms involved in limitation of damage and disease caused by pests is important for optimizing any kind of control. However, it is particularly important in biological control because the mechanism determines whether damage control is really achieved through pest control, rather than general improvements in health that are independent of any effects of applied measures on pests. For example, watering wilted plants may restore their vigor, but this improvement in health is not mediated by pest control, and hence cannot be regarded as resulting from biological

Box 2 Examples of mechanisms and processes that typically do not constitute biological control

Mechanical and physical control

Modification of, e.g., physical barriers and use of mechanical force or manual labor to remove, exclude, kill, or disarm pests.

Cultural control

Agronomic practices, incl. e.g., crop rotation, timing of sowing and harvesting, and intercropping, and optimization of irrigation and fertilization to reduce pest growth.

Auditory and optic control

Pest repellence using non-living noisemakers and visual repellents.

Application of extracts from living organisms

Incl. semiochemicals and bio-derived substances, such as pyrethrum and essential oils.

Intrinsic constitutive resistance

Incl. plant traits conferring antibiosis or antixenosis that reduce plants' susceptibility to pests.

Use of genetic material from biocontrol agents

E.g., making plants intrinsically more resistant by incorporating genetic material from biocontrol agents (e.g., genes encoding Bacillus thuringiensis toxin).

Application of plant growth-promoting substances

E.g., fertilizers or living microorganisms that promote a plant's growth by other mechanisms than targeting the plant's enemies.

Vectoring of biological control agents

High-precision application of biocontrol agents, e.g., using bees or nematodes for delivery. 
control. Some examples of health-promoting actions that cannot be regarded as biological control are listed in Box 2 .

The exact mechanisms whereby a living biocontrol organism negatively affects a pest can be difficult to determine and are unfortunately not always known, especially when they involve antagonistic interactions between microorganisms (Whipps and Gerhardson 2007). We see no reason to exclude some interaction mechanisms from the biocontrol concept because they are indirect, or one of several mechanisms. However, we strongly encourage further studies to clarify mechanisms that are currently obscure. In the following, we outline the main known mechanisms of biological control, as well as some processes that cannot be regarded as biological control. In the future, several more mechanisms may be identified, pending further scientific development.

\section{Predation, parasitism, pathogenicity, and herbivory}

Direct consumption of pests, phytopathogens, and weeds leading to trophic cascades has traditionally been viewed as the most important process reducing damage to plants in natural ecosystems (Hairston et al. 1960). It is also often regarded as the most important type of biological control in cultivated plantations, and encompasses several mechanisms. For example, predators kill and consume their prey (e.g., pests or weed seeds) while insect parasitoids oviposit their eggs on or into their hosts, which are subsequently consumed by the immature offspring. Similarly, some entomopathogenic living agents (especially fungi) may penetrate insects' external cuticle, causing systemic infection, while others (especially bacteria and viruses) cause infection and death of the host following ingestion. In other examples of a direct interference mechanism of biological control, mycoparasitic fungi (e.g., Trichoderma spp.) enfold and attack the hyphae of other fungi then absorb and digest their contents (Benítez et al. 2004; Weindling 1932). Furthermore, the pathogenic mechanisms of phytopathogenic fungi, bacteria, and viruses can be exploited in biological control of invasive plants and agricultural weeds (Evans and Seier 2012; Harding and Raizada 2015). Finally, herbivores can also act as biocontrol agents if they suppress unwanted vegetation (Schwarzländer et al. 2018). All of these modes of attack either kill targeted pests, pathogens, or weeds or reduce their ability to cause damage.

\section{Risk-avoidance behavior of pests}

Animal predators and parasitoids can reduce levels of pest damage inflicted by their prey not only by consumption, but also in other ways, by affecting their prey's behavior (Culshaw-Maurer et al. 2020). Non-consumptive effects of predators caused by visual or chemical cues can reduce the mobility, feeding, and reproduction of some pests through avoidance mechanisms. For example, common flowerbugs induce risk perception in leaf beetles, leading to reductions in mobility, oviposition rates, and thus damage to their willow host plants (Stephan et al. 2017). Similarly, ladybird cues reduce aphids' host plant acceptance on barley (Ninkovic et al. 2013), and predator-induced release of an aphid alarm pheromone induces aphids' 'dropping' predatoravoidance behavior on broad bean plants (Harrison and Preisser 2016; Losey and Denno 1998). These non-consumptive predator effects can be very powerful mechanisms of biological control (Culshaw-Maurer et al. 2020), but have been much less intensively studied than direct consumption. To maximize the full potential of predators and parasitoids for biological control, it is important to distinguish between consumptive and non-consumptive effects in future studies, and investigate how they can be synergistically optimized. For example, breeding of arthropod predators for augmentative biocontrol should not solely focus on their voracity, but also on predator traits that induce a state of fear in their pestilential prey.

\section{Antibiosis}

Many microorganisms produce and excrete biologically active compounds that may have toxic or inhibitory effects on other organisms. For instance, antagonism between microorganisms can involve production and exudation of antimicrobial metabolites or cell-wall degrading enzymes, as reviewed by Whipps and Gerhardson (2007) and Köhl et al. (2019). In cases where beneficial organisms in situ produce biologically active substances that have direct negative effects on pests, this mechanism is a basis for biological control.

\section{Competition}

Ecological competition occurs when two or more organisms vie to acquire one or more limited resources (e.g., light, water, nutrients, and space). For example, in biological control of a plant pathogen using a microorganism, the biocontrol agent might compete with the pathogen for nutrients or either colonization or infection sites (Howell 2003; Whipps 2004). In some cases, both competitors cause at least some harm to the host plant, but in such cases where the strongest competitor causes less harm and replaces a more harmful competitor, this mechanism can be acknowledged as a basis for biological control.

\section{Mobilization of plant intrinsic defenses}

In addition to their constitutive defenses, plants can often launch intrinsic defenses in responses to agents such as mammals, arthropods, and microorganisms. These mechanisms 
are often referred to as priming, induction, immunization, or 'vaccination' (Navarro et al. 2017). Such plant responses can be utilized as mechanisms of biological control if the priming/inducing organism is relatively harmless, and the increase in resistance protects the plant against subsequent attacks by more harmful pests. For example, several species of the fungal genus Trichoderma induce plant defense reactions that subsequently protect the plant against pathogens, either locally or systemically (Contreras-Cornejo et al. 2011; Shoresh et al. 2005). However, microbial communities have extremely complex direct and indirect effects on plants. Thus, we think it is important to limit use of the term biological control to cases where it is known and understood that living agents, applied or resident, are really responsible for observed protective effects. Moreover, induction of elicitors resulting in tolerance to abiotic stress should not be considered as biological control, but as plant-growth promotion (as discussed in a separate paragraph, below). Plants' intrinsic defenses can also be mobilized through semiochemicalbased signals (Bertin et al. 2003) produced by co-occurring companion plants (also discussed below).

\section{Semiochemicals released by living agents}

Many living organisms (e.g., yeasts and plants) release semiochemicals that can affect the behavior of pest organisms (Becher et al. 2012). These processes can be utilized as mechanisms of biological control if they lead to lower pest populations or reductions in damage to focal crops. Such effects can be achieved if, for example, a semiochemical has a manipulative effect on pest behavior, such as repellence or oviposition deterrence. Formally, an active semiochemical must be produced and released in situ by a living organism for this to qualify as a mechanism of biological control. In addition to microorganisms, companion plants can be used to produce semiochemicals for various purposes, e.g., to make crop plantations less attractive to herbivorous pests (Hu et al. 2019; Ninkovic et al. 2016; Tolosa et al. 2019).

\section{Mechanisms that do not constitute bases of biological control}

Mechanisms that do not specifically target pests or pathogens, or do not involve living control agents, do not meet the requirements for biological control according to our definition (Box 1). In many cases, the distinction is relatively clear (Box 2), but two types of mechanisms that are often incorrectly regarded as biological control are discussed below to explain why they do not fulfill the criteria.

\section{Plant-growth promotion}

Some microorganisms (e.g., Penicillium bilaiae) promote plants' growth by enhancing their nutrient uptake and/or use efficiency, abiotic stress tolerance, and/or crop quality traits (Mahanty et al. 2017). They are often referred to as 'biofertilizers' and considered as a sub-group of 'biostimulants' (du Jardin 2015). Increases in plant growth can in turn reduce risk of infection. Claims that certain methods or products promote growth have sometimes been used to avoid regulatory restrictions on formal plant protection products, since microbial agents for controlling plant pathogens need to be registered as microbial pesticides. It can be difficult to separate effects of microbial plant-growth promotion and antagonism toward pathogens. Nevertheless, while acknowledging the difficulty of precisely characterizing the mechanisms underpinning improvement in plant health, we do not accept that plant-growth promotion in itself should be considered a mechanism of biological control.

\section{Vectoring of biocontrol agents}

Microbial biocontrol agents can be applied by using living organisms as vectors, e.g., bumble bees (Van Delm et al. 2015). Similarly, even entomopathogenic nematodes can be viewed as vectors for biological control, as they carry symbiotic bacteria that contribute to infections in target insects, and thus control. Although use of living vectors opens new possibilities for high-precision application of biocontrol agents, it is important to separate the functions of the two organisms. The vectoring per se is not the direct or indirect mechanism of biological control, but merely a means for carrying the agent to the site of activity. However, the mechanism of the biocontrol intervention may be completely dependent on the vector. For instance, after vectoring entomopathogenic nematodes have invaded an insect host and released symbiotic bacteria that infect the insect, the nematodes also reproduce, thus providing an environment for new generations of bacterial biocontrol agents (ShapiroIlan et al. 2012).

\section{Categorizing biological control}

Our proposed scheme for categorizing the various approaches to biological control includes four classes. Two classes solely involve resident biocontrol species in an ecosystem: natural biological control if these species' pest control activities are independent of any targeted human intervention, and conservation biological control if they are actively stimulated by targeted human intervention to improve their pest control potential. The other two classes cover methods involving direct application of additional 
organisms: classical biological control if added organisms are intended to become permanently established, and augmentative biological control if they are mainly intended to be temporarily established.

\section{Resident agents: natural and conservation biological control}

With no deliberate human intervention, resident organisms exert a background level of pest control, through various processes that meet all of the conceptual criteria for biological control and thus can be regarded as natural biological control mechanisms. This form of pest control was not discussed by Eilenberg et al. (2001), but has been widely addressed in the literature in the last 30 years (Heimpel and Mills 2017) (common synonyms are natural control, natural pest control, and biocontrol services), especially in entomological contexts (Landis et al. 2008; Settle et al. 1996). Another form, commonly recognized in plant pathology literature, is soil suppressiveness, referring to the capacity of some soils to limit disease caused by specific soil-borne plant pathogens, even when both the pathogens and susceptible host plants are present (Cook and Baker 1983). Soil suppressiveness can be either general or specific, depending on whether the suppressiveness is due to collective competitive and antagonistic activities of the soil microbiome or activities of just one or a few microbial taxa (Kwak and Weller 2013). We argue that suppressiveness that occurs spontaneously in the absence of targeted cultural practices, commonly referred to as natural or native soil suppressiveness (Siegel-Hertz et al. 2018), is an example of natural biological control. Similarly, predation of weed seeds by resident vertebrates and invertebrates (White et al. 2007) would fall within natural biological control of weeds.

Targeted practices are often used to stimulate increases in the populations and efficacy of resident biocontrol agents. In line with Eilenberg et al. (2001), we define such stimulation of resident agents as conservation biological control. Actions to manage invertebrate biocontrol agents may include, for example, establishment of flower strips that provide nectar, pollen, shelter, or alternate prey for predators and parasitoids (Jonsson et al. 2008). Deliberate reduction in pesticide use with the explicit goal of enhancing populations of natural enemies (Bell et al. 2016; Bommarco et al. 2011), commonly employed in integrated pest management strategies, also falls within conservation biological control. Management actions intended to induce and maintain temporary soil suppressiveness are also forms of conservation biological control and may include various cultural practices (Kwak and Weller 2013), such as appropriate cultivar mixing and stimulation of beneficial plant-soil feedback processes.

Although conservation biological control is one of the main categories of the new framework, we strongly recommended exclusion of management practices that target pest organisms directly, rather than by stimulating biocontrol agents, from the framework. If the practices target pest populations directly, they should instead be referred to as cultural pest control (Eilenberg et al. 2001).

\section{Added agents: classical and augmentative biological control}

Biological control can involve mass rearing and release of additional organisms to control pests (Brodeur et al. 2018; van Lenteren 2012). One main type of this strategy is the introduction of exotic biocontrol agents for permanent establishment and hence permanent control of targeted pests. This is referred to here, and elsewhere, as classical biological control, because it has been used quite extensively ever since the second half of the nineteenth century (Eilenberg et al. 2001). Thus, this category of biocontrol is well-established, well-defined, and well-documented with thousands of introductions to control insect pests and weeds during the last 130 years (Cock et al. 2016; Winston et al. 2014), although there has been a decline in classical biological control introductions in more recent times due to the greater focus on risks than benefits of biocontrol introductions, beginning in the 1990s (Heimpel and Cock 2018). We argue that classical biological control should be kept as a separate term to be used irrespectively of whether the targeted pest is exotic or native and they have co-evolved or not (sometimes referred to as neoclassical and new association biological control, respectively (Eilenberg et al. 2001)). Some authors (incl. Heimpel and Mills 2017) have suggested that the term classical biological control should be replaced by importation biological control as the latter term is more descriptive and intuitive. However, reforming terminology is always difficult, and our review of the use of synonymous terms clearly shows that importation biological control has been ignored by most authors (Appendix 1). Here we submit to the great majority of authors who use the term classical biological control.

In many cases, however, the purpose of applying a biological control agent is to control a pest only temporarily (Lacey et al. 2015; Stewart et al. 2010). For example, pest control in agricultural fields is often temporally restricted to the summer, and greenhouse cultures may be disrupted by harvesting, after which all biocontrol organisms are expected to die due to food shortage, suboptimal environmental conditions, and/or disinfection. Approaches employing such non-permanent biological control have been particularly burdened by a hodgepodge of terms, including augmentative biological control, inundative biological control, and inoculative biological control. We suggest that augmentative biological control should be used for this major category for two reasons. First, this term is frequently used in 
the literature (Appendix 1). Second, other terminological options are confusing and have been used in inconsistent ways. Unfortunately, in a few instances the term augmentative biological control has also been used to jointly describe releases of natural enemies and measures taken to conserve and enhance the activity of natural enemies already present in the system (Capinera 2008), although this very broad use of the term seems uncommon. Thus, generally most authors agree that augmentative biological control refers to the addition of biocontrol agents with the intention to control pests temporarily.

However, the term augmentative biological control was discouraged by Eilenberg et al. (2001), largely because it does not distinguish between inundative releases, where the effect is due to the released organisms alone and no reproduction is expected, and inoculative releases, where the released organisms are expected to reproduce and provide more long-term (but still non-permanent) control. A recent book by two of these authors (Hajek and Eilenberg 2018) maintains the separation of inundative and inoculative biological control, while retaining augmentative as an aggregate term. However, in many cases the extent of postrelease reproduction is not known, making this subdivision difficult to apply in practice. This difficulty is probably the most important reason why the terms inundative and inoculative biological control are rarely used in the literature, while the term augmentative biological control is frequently used (Appendix 1). Adding to the confusion, inoculative biological control has also been used synonymously with classical biological control (van Lenteren 2012). We therefore advocate use of the broader term augmentative biological control for all cases of non-permanent pest control, whether the released organisms reproduce or not. It should be emphasized, however, that use of the broader term augmentative should not be taken to imply that understanding ecological aspects of the biocontrol solution (e.g., any propagation and dispersal of the agent) is less important.

\section{What does the legislation say about biological control?}

The biocontrol categories identified above are subject to very different types of legislation and regulatory frameworks. Conservation biological control is essentially unregulated, unless it involves regulated management practices or products, and is not dealt with further. Additionally, regulatory approaches differ among countries. Space limitations preclude a full account of this topic here, but this section provides examples of how typical regulatory measures applicable to different categories treat the concept of biological control.
Classical biological control is generally covered by legislation targeting environmental protection and risk assessment, especially regarding importation of exotic species and quarantine rules (FAO 2017; Sheppard et al. 2003). For instance, in Australia, classical biological control is regulated by a Biological Control Act, a Quarantine Act, and an Environment Protection and Biodiversity Conservation Act, whereas in New Zealand a Hazardous Substances and New Organisms Act and a Biosecurity Act apply (Ehlers et al. 2020; Goldson et al. 2010). Risk evaluation of classical biocontrol initiatives are strongly influenced by pest risk analysis, i.e., determining whether an introduced agent may itself become a problematic pest (FAO 2017).

For augmentative biological control, regulatory conditions are entirely different for macro- and microorganisms. In the European Union (EU), there is no common regulatory framework for invertebrates (macroorganisms), but several member states have introduced national, mandatory pre-market authorization of invertebrate biocontrol agents (Mason et al. 2017). The rules regarding invertebrate biocontrol agents focus on environmental risks and have been integrated into specific, national, regulatory frameworks (EPPO 2014; Swedish Government 2016), and the term 'biological control agents' may even appear in the title of regulatory documents.

By contrast, rules concerning augmentative biological control with microorganisms are usually incorporated into pesticide regulations (FAO/WHO 2017; Kabaluk et al. 2010) and pay attention to both environmental and human risks. Following established rationales for pesticides, such legislation does not view a microorganism primarily as a biocontrol agent, but as an 'active substance' of the pest control product. For instance, both the data requirements (EU 2013) and uniform principles (EU 2011) for authorization of microbial plant protection products (PPP) in the EU refer only once to 'biological control' or 'biocontrol.' Both state that special attention should be paid to organisms used for biological control and organisms that play an important role in integrated pest management. Interestingly, this reference to biological control in the legislation for PPPs does not relate to the microorganism actually evaluated according to the same regulation for use in augmentative biological control, but to the risk for negative effects of the microbial PPPs on non-target natural enemies exerting biological control. Similarly, in the USA, microorganisms for augmentative biological control are regulated under the common framework for pesticides, FIFRA (Federal Insecticide, Fungicide, and Rodenticide Act) (USA Environmental Protection Agency 2021). Like the European framework, this legislation does not primarily refer to the microorganisms as biological control agents but rather as 'microbial pesticides,' a type of 'biopesticides.' 
Recently introduced EU regulation for fertilizers (EU 2019) covers plant growth-promoting microorganisms as a type of biostimulant. Microbial biostimulants are distinguished from microbial plant protection products (i.e., biological control agents) in that microorganisms strengthening plants' intrinsic defenses to abiotic stress will be covered by the fertilizers regulation, while those strengthening intrinsic defenses to biotic stressors, e.g., plant pathogens, will still be covered by the PPP framework. Although this division cuts across different action mechanisms of plant beneficial microorganisms and is not strongly related to potential hazards, it is consistent with our proposal for updated terminology of biological control.

The above examples illustrate that rather than clarifying the concept and terminology of biological control, current regulatory systems contribute to the confusion and lack of a common conceptual framework for biological control. Thus, an updated framework for biological control could contribute to more uniform and appropriate regulatory approaches to biological control, and in the longer term to more efficient approvals and authorization of biocontrol solutions and products.

\section{Conclusions}

Based on our review, we propose that biological control should be based on three key principles. First, biological control involves a living agent directly or indirectly targeting a pest, thereby reducing damage from a human perspective. Second, damage must be reduced by pest control, rather than via general health improvement. Thus, identification of the mechanism(s) involved is important. In cases where a nature-based method to control pests does not meet the criteria for biological control, it is likely to fall within the other recognized area of bioprotection (Fig. 1). The third principle is that all biological control methods can be conveniently classified in four main categories: Natural biological control (if there is no deliberate human intervention), Conservation biological control (involving human stimulation of resident agents of biological control), Augmentative biological control (human addition of biocontrol agents, temporarily augmenting the population of biocontrol agents), and Classical biological control (adding new biocontrol agents for proliferation and permanent establishment). Building on previous work (Eilenberg et al. 2001; Heimpel and Mills 2017), these polished categories comprise a holistic ensemble, with improved clarity and pragmatism (Fig. 2).

We hope that this terminological and conceptual platform for biological control will help understanding,

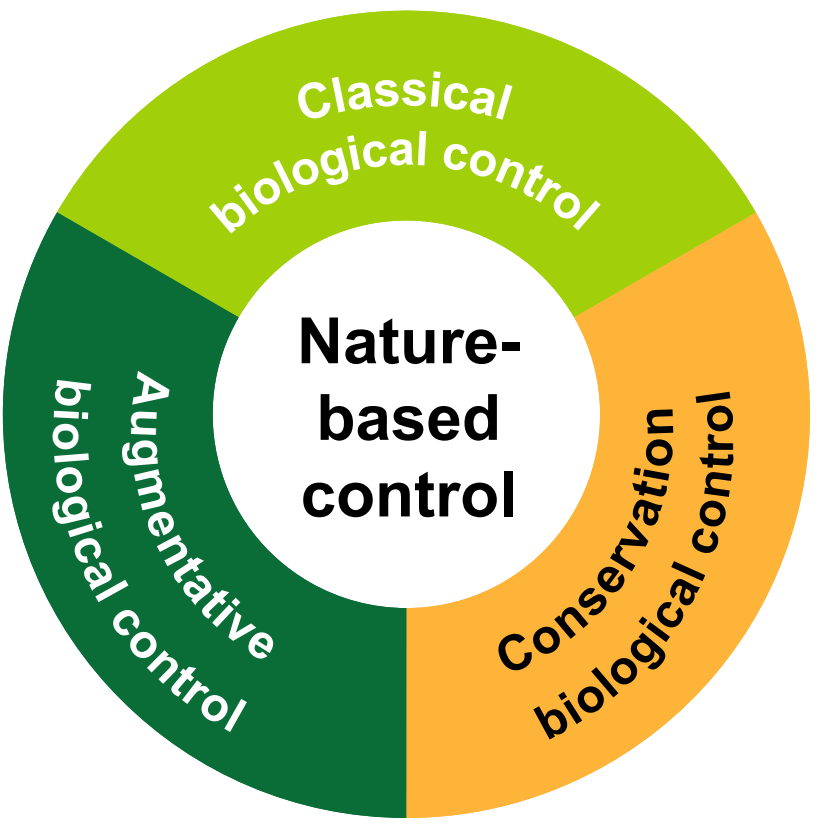

Fig. 2 The categories of biological control. Natural biological control denotes the ecosystem service carried out by resident natural enemies of pests and pathogens in the absence of human intervention. The other three categories typically depend on and interact with this baseline of control, to various degrees, hence its placement in the middle. Conservation biological control denotes the human stimulation of resident natural enemies to enhance their control of pests and pathogens. Augmentative biological control refers to human addition of mass-reared biocontrol agents, temporarily augmenting their population densities in a targeted area. Finally, classical biological control denotes human addition of new biocontrol agents for proliferation and long-term establishment. These three categories can be used individually or be combined (as indicated by the circle connecting each category with the other two)

optimization, and regulation of biological pest control for human and environmental good. Furthermore, as the terminology is globally applicable, irrespective of the taxonomic field, and area of use, we urge scientists, as well as legislators, and industrial representatives to embrace it. With a globally accepted conceptual framework and terminology, we foresee a bright future for biological control within science, industry, and society in general.

\section{Authors' contributions}

All authors participated in preparatory meetings to formulate the review questions. JAS, IS, and MV wrote the first draft. All authors contributed critically to the draft and gave final approval for publication.

Supplementary Information The online version contains supplementary material available at https://doi.org/10.1007/s10340-021-01354-7. 
Acknowledgements This work was funded by the SLU Centre for Biological Control (part of the Swedish University of Agricultural Sciences) and Formas-a Swedish Research Council for Sustainable Development (grant nos. 2018-01036, 2018-01420, and 2019-00727).

Funding Open access funding provided by Swedish University of Agricultural Sciences.

\section{Declarations}

Conflicts of interest The authors declare that they have no conflicts of interest.

Consent for publication All authors have approved the submission and publication of this paper.

Open Access This article is licensed under a Creative Commons Attribution 4.0 International License, which permits use, sharing, adaptation, distribution and reproduction in any medium or format, as long as you give appropriate credit to the original author(s) and the source, provide a link to the Creative Commons licence, and indicate if changes were made. The images or other third party material in this article are included in the article's Creative Commons licence, unless indicated otherwise in a credit line to the material. If material is not included in the article's Creative Commons licence and your intended use is not permitted by statutory regulation or exceeds the permitted use, you will need to obtain permission directly from the copyright holder. To view a copy of this licence, visit http://creativecommons.org/licenses/by/4.0/.

\section{References}

Barratt BIP, Moran VC, Bigler F, van Lenteren JC (2018) The status of biological control and recommendations for improving uptake for the future. Biocontrol 63:155-167. https://doi. org/10.1007/s10526-017-9831-y

Becher PG et al (2012) Yeast, not fruit volatiles mediate Drosophila melanogaster attraction, oviposition and development. Funct Ecol 26:822-828. https://doi.org/10.111 $1 / \mathrm{j} .1365-2435.2012 .02006 . x$

Bell A, Zhang W, Nou K (2016) Pesticide use and cooperative management of natural enemy habitat in a framed field experiment. Agric Syst 143:1-13. https://doi.org/10.1016/j. agsy.2015.11.012

Benítez T, Rincón AM, Limón MC, Codón AC (2004) Biocontrol mechanisms of Trichoderma strains. Int Microbiol 7:249-260

Bertin C, Yang X, Weston LA (2003) The role of root exudates and allelochemicals in the rhizosphere. Plant Soil 256:67-83. https ://doi.org/10.1023/A:1026290508166

Bommarco R, Miranda F, Bylund H, Björkman C (2011) Insecticides suppress natural enemies and increase pest damage in cabbage. J Econ Entomol 104:782-791. https://doi.org/10.1603/ec10444

Brodeur J, Abram PK, Heimpel GE, Messing RH (2018) Trends in biological control: public interest, international networking and research direction. Biocontrol 63:11-26. https://doi. org/10.1007/s10526-017-9850-8

Bruce TJ et al (2005) Response of economically important aphids to components of Hemizygia petiolata essential oil. Pest Manag Sci 61:1115-1121. https://doi.org/10.1002/ps.1102

Capinera JL (2008) Encyclopedia of Entomology, 2nd edn. Springer, Dordrecht

Cock MJW, Murphy ST, Kairo MTK, Thompson E, Murphy RJ, Francis AW (2016) Trends in the classical biological control of insect pests by insects: an update of the BIOCAT database. Biocontrol 61:349-363. https://doi.org/10.1007/s10526-016-9726-3

Contreras-Cornejo HA, Macías-Rodríguez L, Beltrán-Peña E, Herrera-Estrella A, López-Bucio J (2011) Trichoderma-induced plant immunity likely involves both hormonal- and camalexindependent mechanisms in Arabidopsis thaliana and confers resistance against necrotrophic fungi Botrytis cinerea. Plant Signal Behav 6:1554-1563. https://doi.org/10.4161/psb.6.10.17443

Cook RJ, Baker KF (1983) The nature and practice of biological control of plant pathogens. APS Press, St. Paul, MN, USA

Culshaw-Maurer M, Sih A, Rosenheim JA (2020) Bugs scaring bugs: enemy-risk effects in biological control systems. Ecol Lett 23:1693-1714. https://doi.org/10.1111/ele.13601

Dedrick RM et al (2019) Engineered bacteriophages for treatment of a patient with a disseminated drug-resistant Mycobacterium abscessus. Nat Med 25:730-733. https://doi.org/10.1038/s4159 1-019-0437-z

Di Giallonardo F, Holmes EC (2015) Viral biocontrol: grand experiments in disease emergence and evolution. Trends Microbiol 23:83-90. https://doi.org/10.1016/j.tim.2014.10.004

du Jardin P (2015) Plant biostimulants: Definition, concept, main categories and regulation. Scientia Horticulturae 196:3-14. https ://doi.org/10.1016/j.scienta.2015.09.021

Ehlers GAC, Caradus JR, Fowler SV (2020) The regulatory process and costs to seek approval for the development and release of new biological control agents in New Zealand. Biocontrol 65:1-12. https://doi.org/10.1007/s10526-019-09975-9

Eilenberg J, Hajek A, Lomer C (2001) Suggestions for unifying the terminology in biological control. Biocontrol 46:387-400. https ://doi.org/10.1023/A:1014193329979

EPPO (2014) PM 6/2 (3) Import and release of non-indigenous biological control agents. EPPO Bulletin 44:320-329. https://doi. org/10.1111/epp.12153

EU (2011) Commission Regulation (EU) No 546/2011 implementing regulation (EC) No. 1107/2009 of the European parliament and of the council as regards uniform principles for evaluation and authorisation of plant protection products. https://eur-lex.europ a.eu/eli/reg/2011/546/oj

EU (2013) Commission regulation (EU) No 283/2013 setting out the data requirements for active substances, in accordance with Regulation (EC) No. 1107/2009 of the European parliament and of the council concerning the placing of plant protection products on the market. https://eur-lex.europa.eu/eli/reg/2013/283/oj

EU (2019) Regulation (EU) 2019/1009 of the European parliament and of the council laying down rules on making available on the market of EU fertilizing products and amending regulations (EC) no. $1069 / 2009$ and (EC) no. $1107 / 2009$ and repealing regulation (EC) no. 2003/2003.https://eur-lex.europa.eu/eli/reg/2019/1009/oj

Evans HC, Seier MK (2012) Safety and regulation of microbial control of weeds. In: Sundh I, Wilcks A, Goettel MS (eds) Beneficial microorganisms in agriculture, food and the environment-safety assessment and regulation. CAB International, Wallingford, pp $112-137$

Falcon LA (1982) Use of pathogenic viruses as agents for the biological control of insect pests. In: Anderson RM, May RM (eds) Population biology of infectious diseases. Springer, Berlin, pp 191-210

FAO (2017) Guidelines for the export, shipment, import and release of biological control agents and other beneficial organisms. International Standards for Phytosanitary Measures, ISPM 3. https://assets.ippc.int/static/media/files/publication/en/2017/05/ ISPM_03_2005_En_2017-05-23_PostCPM12_InkAm.pdf

FAO/WHO (2017) International code of conduct on pesticide management: Guidelines for the registration of microbial, botanical and semiochemical pest control agents for plant protection and public health uses. https://www.who.int/publications/i/item/WHO-HTMNTD-WHOPES-2017.05 
Forterre P (2010) Defining life: the virus viewpoint. Origins Life Evol Biosph 40:151-160. https://doi.org/10.1007/s11084-010-9194-1

Goldson SL, Frampton ER, Ridley GS (2010) The effects of legislation and policy in New Zealand and Australia on biosecurity and arthropod biological control research and development. Biol Control 52:241-244. https://doi.org/10.1016/j.biocontrol.2009.03.006

Gray JA, Chandry PS, Kaur M, Kocharunchitt C, Bowman JP, Fox EM (2018) Novel biocontrol methods for Listeria monocytogenes biofilms in food production facilities. Front Microbiol 3:605. https ://doi.org/10.3389/fmicb.2018.00605

Hairston NG, Smith FE, Slobodkin LB (1960) Community structure population control and competition. Am Nat 94:421-425. https:// doi.org/10.1086/282146

Hajek A, Eilenberg J (2018) Natural enemies — an introduction to biological control. Cambridge University Press, Cambridge. https:// doi.org/10.1017/CBO9780511811838

Harding DP, Raizada MN (2015) Controlling weeds with fungi, bacteria and viruses: a review. Front Plant Sci 6:569. https://doi. org/10.3389/fpls.2015.00659

Harrison KV, Preisser EL (2016) Dropping behavior in the pea aphid (Hemiptera: Aphididae): how does environmental context affect antipredator responses? J Insect Sci 16:89. https://doi.org/10.1093/ jisesa/iew066

Heimpel GE, Cock MJW (2018) Shifting paradigms in the history of classical biological control. Biocontrol 63:27-37. https://doi. org/10.1007/s10526-017-9841-9

Heimpel GE, Mills NJ (2017) Biological control—ecology and applications. Cambridge University Press, Cambridge. https://doi. org/10.1017/9781139029117

Howell CR (2003) Mechanisms employed by Trichoderma species in the biological control of plant diseases: the history and evolution of current concepts. Plant Dis 87:4-10. https://doi.org/10.1094/ pdis.2003.87.1.4

Hu L, Ye M, Erb M (2019) Integration of two herbivore-induced plant volatiles results in synergistic effects on plant defence and resistance plant. Cell Environ 42:959-971. https://doi.org/10.1111/ pce. 13443

Ingabire CM et al (2017) Community-based biological control of malaria mosquitoes using Bacillus thuringiensis var. israelensis (Bti) in Rwanda: community awareness, acceptance and participation. Malar J 16:399. https://doi.org/10.1186/s12936-017-2046-y

International Biocontrol Manufacturers Association (2018) IBMA white paper: New EU regulatory framework for bioprotection agents. https://www.ibma-global.org/upload/attach-document/ ibma-white-paper-web-final-a5-spreads.pdf

Isman MB (2006) Botanical insecticides, deterrents, and repellents in modern agriculture and in an increasingly regulated world. Ann Rev Entomol 51:45-66. https://doi.org/10.1146/annur ev.ento.51.110104.151146

Jäkel T, Promkerd P, Sitthirath R, Guedant P, Khoprasert Y (2019) Biocontrol of rats in an urban environment in Southeast Asia using Sarcocystis singaporensis. Pest Manag Sci 75:2148-2157. https:// doi.org/10.1002/ps.5335

Jonsson M, Wratten SD, Landis DA, Gurr GM (2008) Recent advances in conservation biological control of arthropods by arthropods. Biol Control 45:172-175. https://doi.org/10.1016/j.biocontrol .2008 .01 .006

Jordan K et al (2014) Microbes versus microbes: control of pathogens in the food chain. J Sci Food Agric 94:3079-3089. https://doi. org/10.1002/jsfa.6735

Kabaluk JT, Goettel MS, Svircev AM, Woo SG (eds) (2010) Use and regulation of microbial pesticides in representative jurisdictions worldwide.IOBC Global. https://www.iobc-global.org/download/ Microbial_Regulation_Book_Kabaluk_et_al_2010.pdf

Koch A et al (2016) An RNAi-based control of Fusarium graminearum infections through spraying of long dsRNAs involves a plant passage and is controlled by the fungal silencing machinery. PLoS Pathog 12:e1005901. https://doi.org/10.1371/journal.ppat.10059 01

Köhl J, Kolnaar R, Ravensberg WJ (2019) Mode of action of microbial biological control agents against plant diseases: relevance beyond efficacy frontiers in plant. Science 10:845. https://doi.org/10.3389/ fpls.2019.00845

Koonin EV, Starokadomskyy P (2016) Are viruses alive? The replicator paradigm sheds decisive light on an old but misguided question. Stud History Philos Biol Biomed Sci 59:125-134. https://doi. org/10.1016/j.shpsc.2016.02.016

Kwak YS, Weller DM (2013) Take-all of wheat and natural disease suppression: a review. Plant Pathol J 29:125-135. https://doi. org/10.5423/PPJ.SI.07.2012.0112

Labuschagne L, Swanepoel LH, Taylor PJ, Belmain SR, Keith M (2016) Are avian predators effective biological control agents for rodent pest management in agricultural systems? Biol Control 101:94-102. https://doi.org/10.1016/j.biocontrol.2016.07.003

Lacey LA, Grzywacz D, Shapiro-Ilan DI, Frutos R, Brownbridge M, Goettel MS (2015) Insect pathogens as biological control agents: back to the future. J Invertebr Pathol 132:1-41. https:// doi.org/10.1016/j.jip.2015.07.009

Landis DA, Gardiner MM, van der Werf W, Swinton SM (2008) Increasing corn for biofuel production reduces biocontrol services in agricultural landscapes. Proc Natl Acad Sci 105:20552-20557. https://doi.org/10.1073/pnas.0804951106

Losey JE, Denno RF (1998) Positive predator-predator interactions: enhanced predation rates and synergistic suppression of aphid populations. Ecology 79:2143-2152. https://doi. org/10.1890/0012-9658(1998)079[2143:PPPIEP]2.0.CO;2

Mahanty T, Bhattacharjee S, Goswami M, Bhattacharyya P, Das B, Ghosh A, Tribedi P (2017) Biofertilizers: a potential approach for sustainable agriculture development. Environ Sci Pollut Res 24:3315-3335. https://doi.org/10.1007/s11356-016-8104-0

Mason PG, Everatt MJ, Loomans AJM, Collatz J (2017) Harmonizing the regulation of invertebrate biological control agents in the EPPO region: using the NAPPO region as a model. EPPO Bulletin 47:79-90. https://doi.org/10.1111/epp.12355

Navarro MOP, Simionato AS, Barazetti AR, dos Santos IMO, Cely MVT, Chryssafidis AL, Andrade G (2017) Disease-induced resistance and plant immunization using microbes. In: Singh DP, Singh HB, Prabha R (eds) Plant-Microbe interactions in agroecological perspectives: fundamental mechanisms, methods and functions. Springer, Singapore, Singapore, pp 447-465. https:// doi.org/10.1007/978-981-10-5813-4_22

Ninkovic V, Feng Y, Olsson U, Pettersson J (2013) Ladybird footprints induce aphid avoidance behavior. Biol Control 65:63-71. https:// doi.org/10.1016/j.biocontrol.2012.07.003

Ninkovic V, Markovic D, Dahlin I (2016) Decoding neighbour volatiles in preparation for future competition and implications for tritrophic interactions. Perspect Plant Ecol Evol Syst 23:11-17. https://doi.org/10.1016/j.ppees.2016.09.005

Pertot I, Giovannini O, Benanchi M, Caffi T, Rossi V, Mugnai L (2017) Combining biocontrol agents with different mechanisms of action in a strategy to control Botrytis cinerea on grapevine. Crop Prot 97:85-93. https://doi.org/10.1016/j.cropro.2017.01.010

Santos A, Navascués E, Bravo E, Marquina D (2011) Ustilago maydis killer toxin as a new tool for the biocontrol of the wine spoilage yeast Brettanomyces bruxellensis. Int J Food Microbiol 145:147154. https://doi.org/10.1016/j.ijfoodmicro.2010.12.005

Schwarzländer M, Hinz HL, Winston RL, Day MD (2018) Biological control of weeds: an analysis of introductions, rates of establishment and estimates of success, worldwide. Biocontrol 63:319331. https://doi.org/10.1007/s10526-018-9890-8

Settle WH, Ariawan H, Astuti ET, Cahyana W, Hakim AL, Hindayana D, Lestari AS (1996) Managing tropical rice pests through 
conservation of generalist natural enemies and alternative prey. Ecology 77:1975-1988. https://doi.org/10.2307/2265694

Shapiro-Ilan DI, Han R, Dolinksi C (2012) Entomopathogenic nematode production and application technology. J Nematol 44:206-217

Sheppard AW, Hill R, DeClerck-Floate RA, McClay A, Olckers T, Quimby PC Jr, Zimmermann HG (2003) A global review of riskbenefit-cost analysis for the introduction of classical biological control agents against weeds: a crisis in the making? Biocontrol News Inf 24:91N-108N. https://www.cabi.org/bni/FullTextPD F/2004/20043008816.pdf

Shoresh M, Yedidia I, Chet I (2005) Involvement of jasmonic acid/ ethylene signaling pathway in the systemic resistance induced in cucumber by Trichoderma asperellum T203. Phytopathology 95:76-84. https://doi.org/10.1094/phyto-95-0076

Siegel-Hertz K, Edel-Hermann V, Chapelle E, Terrat S, Raaijmakers JM, Steinberg C (2018) Comparative microbiome analysis of a Fusarium wilt suppressive soil and a Fusarium wilt conducive soil from the Châteaurenard region. Front Microbiol 9:568. https ://doi.org/10.3389/fmicb.2018.00568

Smith HS (1919) On some phases of insect control by the biological method. J Econ Entomol 12:288-292. https://doi.org/10.1093/ jee/12.4.288

Stenberg JA (2017) A conceptual framework for integrated pest management. Trends Plant Sci 22:759-769. https://doi.org/10.1016/j. tplants.2017.06.010

Stephan JG, Stenberg JA, Björkman C (2017) Consumptive and nonconsumptive effect ratios depend on interaction between plant quality and hunting behavior of omnivorous predators. Ecol Evol 7:2327-2339. https://doi.org/10.1002/ece3.2828

Stewart A, Brownbridge M, Hill R, Jackson T (2010) Utilizing soil microbes for biocontrol. In: Dixon R, Tilston E (eds) Soil microbiology and sustainable crop production. Springer, Berlin, pp 315-371. https://doi.org/10.1007/978-90-481-9479-7_9

Swedish Government (2016) Förordning (2016:402) om nematoder, insekter och spindeldjur som bekämpningsmedel. https ://www.riksdagen.se/sv/dokument-lagar/dokument/svensk-forfa ttningssamling/forordning-2016402-om-nematoder-insek ter-och_sfs-2016-402

Tahvanainen JO, Root RB (1972) The influence of vegetational diversity on the population ecology of a specialized herbivore, Phyllotreta cruciferae (Coleoptera: Chrysomelidae). Oecologia 10:321-346. https://doi.org/10.1007/BF00345736

Thakur M, Sohal BS (2013) Role of elicitors in inducing resistance in plants against pathogen Infection: a review ISRN. Biochemistry 2013:762412. https://doi.org/10.1155/2013/762412
Tolosa TA et al (2019) Molasses grass induces direct and indirect defense responses in neighbouring maize plants. J Chem Ecol 45:982-992. https://doi.org/10.1007/s10886-019-01122-z

USA Environmental Protection Agency (2021) Pesticide registration manual: Chapter 3-Additional considerations for biopesticide products. https://www.epa.gov/pesticide-registration/pesticideregistration-manual-chapter-3-additional-considerations

Van Delm T, Van Beneden S, Mommaerts V, Melis P, Stoffels K, Wäckers F, Baets W (2015) Control of Botrytis cinerea in strawberries with Gliocladium catenulatum vectored by bumblebees. J Berry Res 5:23-28

van Lenteren JC (2012) The state of commercial augmentative biological control: plenty of natural enemies, but a frustrating lack of uptake. Biocontrol 57:1-20. https://doi.org/10.1007/s1052 6-011-9395-1

van Nood E et al (2013) Duodenal infusion of donor feces for recurrent Clostridium difficile. N Engl J Med 368:407-415. https://doi. org/10.1056/NEJMoa1205037

Weindling R (1932) Trichoderma lignorum as a parasite of other soil fungi. Phytopathology 22:837-845

Whipps JM (2004) Prospects and limitations for mycorrhizas in biocontrol of root pathogens. Can J Bot 82:1198-1227. https://doi. org/10.1139/b04-082

Whipps JM, Gerhardson B (2007) Biological pesticides for control of seed-and soil-borne plant pathogens. In: van Elsas JD, Jansson JK, Trevors JT (eds) Modern soil microbiology, 2nd edn. CRC Press, Boca Raton

White SS, Renner KA, Menalled FD, Landis DA (2007) Feeding preferences of weed seed predators and effect on weed emergence. Weed Sci 55:606-612. https://doi.org/10.1614/WS-06-162.1

Winston RL, Schwarzländer M, Hinz HL, Day MD, Cock MJW, Julien MH (2014) Biological control of weeds: a world catalogue of agents and their target weeds, 5th edn. United States Department of Agriculture Forest Service, Morgantown. https://www.ibioc ontrol.org/catalog/JulienCatalogueFHTET_2014_04.pdf

Witzgall P, Kirsch P, Cork A (2010) Sex pheromones and their impact on pest management. J Chem Ecol 36:80-100. https://doi. org/10.1007/s10886-009-9737-y

Zhu F, Xu J, Palli R, Ferguson J, Palli SR (2011) Ingested RNA interference for managing the populations of the Colorado potato beetle Leptinotarsa decemlineata. Pest Manag Sci 67:175-182. https ://doi.org/10.1002/ps.2048

Publisher's Note Springer Nature remains neutral with regard to jurisdictional claims in published maps and institutional affiliations. 